Grasz, S., T. Keisanen, F. Oloff, M. Rauniomaa, I. Rautiainen \& M. Siromaa (toim.) 2020. Menetelmällisiä käänteitä soveltavassa kielentutkimuksessa - Methodological Turns in Applied Language Studies. AFinLAn vuosikirja 2020. Suomen soveltavan kielitieteen yhdistyksen julkaisuja n:o 78. Jyväskylä. s. 258-262.

\author{
Juha Jalkanen
}

Jyväskylän yliopisto

\title{
Soveltava kielitiede opetuksen ja tutkimuksen rajapinnalla
}

\section{Johdanto}

Soveltava kielitiede on monitieteinen tieteenala, joka pyrkii tunnistamaan ja tutkimaan kieleen liittyviä arjen ilmiöitä ja ongelmia sekä tarjoamaan niihin ratkaisuja (esim. Hellermann 2015). Monet nyky-yhteiskunnan arjen ilmiöistä ja ongelmista ovat luonteeltaan monitahoisia, niin sanottuja viheliäisiä ongelmia. Viheliäisille ongelmille tyypillistä on, että ne ovat ainutlaatuisia, vaikeasti määriteltäviä, monitahoisia ja riippuvaisia toisistaan, perinteiset organisaatio- ja tieteenalarajat ylittäviä, kytköksissä toisiinsa, jatkuvasti muuttuvia ja mahdottomia ratkaista lopullisesti (Irwin \& Kossoff 2020). Niihin liittyy myös usein erilaisia arvoja, asenteita ja näkökulmia. Viheliäisten ongelmien luonteesta johtuu se, että ratkaisuja etsiessä tulee harvoin (jos koskaan) kerralla valmista, sillä ongelmat muuttuvat ja prosessin edetessä joudutaan usein kokeilemaan erilaisia ratkaisuja ja tekemään muutoksia jo tehtyihin ratkaisuihin. Ratkaisujen löytäminen edellyttää yleensä eri alojen asiantuntijoiden yhteistyötä. Viheliäisten ongelmien äärellä soveltavat kielentutkijat ovatkin alka- 
neet etsiä menetelmällisiä ratkaisuja, joiden avulla voidaan vastata yhteiskunnan monitasoisiin ja -tahoisiin haasteisiin.

Monille uusista menetelmällisistä ratkaisuista on yhteistä, että niissä liikutaan jollakin rajapinnalla - esimerkiksi opetuksen ja tutkimuksen (esim. Jakonen, Jalkanen, Paakkinen \& Suni 2015) tai tieteen ja taiteen (esim. Paulasto \& Pöyhönen 2020). Toinen yhdistävä tekijä on vuorovaikutus, jota voi tapahtua niin tutkijoiden, tutkimukseen osallistuvien ja tutkimustuloksia hyödyntävien kuin tieteenalojen ja menetelmällisten viitekehystenkin välillä. Tarkastelen seuraavaksi tutkimuksen ja opetuksen rajapintaa sekä siihen liittyvää vuorovaikutusta yliopistonäkökulmasta. Lopuksi pohdin sitä, miten opetuksen ja tutkimuksen rajapinnalta nousevat kysymykset viitoittavat soveltavan kielitieteen kehittymistä.

\section{Tutkimukseen perustuva(n) opetuksen kehittäminen}

Yliopistossa opetuksen ja tutkimuksen liitto on luontainen ja se nousee selkeästi esille myös lainsäädännössä määritellyssä tehtävässä. Yliopistolain (2009) mukaan

[y]liopistojen tehtävänä on edistää vapaata tutkimusta sekä tieteellistä ja taiteellista sivistystä, antaa tutkimukseen perustuvaa ylintä opetusta sekä kasvattaa opiskelijoita palvelemaan isänmaata ja ihmiskuntaa. Tehtäviään hoitaessaan yliopistojen tulee tarjota mahdollisuuksia jatkuvaan oppimiseen, toimia vuorovaikutuksessa muun yhteiskunnan kanssa sekä edistää tutkimustulosten ja taiteellisen toiminnan yhteiskunnallista vaikuttavuutta. (lihavointi kirjoittajan)

Tehtävän kuvaus jättää kuitenkin tilaa erilaisille tulkinnoille. Se, että opetus perustuu tutkimukseen, voidaan nimittäin tulkita ainakin kolmella eri tavalla. Yliopistoissa yleisin tulkinta lienee se, että tutkimukseen perustuva opetus tarkoittaa sitä, että opetetaan sitä mitä tutkitaan. Toinen, erityisesti tutkivan opettajuuden suuntausten myötä kehittynyt tulkinta taas puolestaan on, että tutkitaan sitä, miten opetetaan. Kolmas tulkinta on tavallaan kahden edellisen yhdistelmä - siinä opetusta kehitetään tutkimustiedon avulla. Tutkimustieto voi olla oman tutkimuksen kautta syntynyttä tai jonkun muun tahon tuottamaa ja se voi koskea opetuksen sisältöjä, menetelmiä tai molempia. Kaikki kolme tulkintaa luovat tutkimuksen ja opetuksen vuoropuhelua, mutta eri tavoin.

Olipa näkökulma sitten mikä tahansa kolmesta edellä mainitusta, tutkimukseen perustuvassa opetuksessa kohtaavat aina kaksi kontekstia: tutkimuksen konteksti ja opetuksen konteksti. Tutkimuksen konteksti on luonteeltaan hidas ja kytkeytyy globaaleihin tieteen tekemisen virtauksiin. Niinpä tutkimusprosessi vie aikaa, vaikka se toteutettaisiin kuinka ketterästi. Opetuksen konteksti taas on nopea ja ensisijaisesti 
lokaali. Tutkimus ja opetus kulkevat siis jo lähtökohtaisesti eri aikajänteissä, joten missä, milloin ja miten ne kohtaavat?

Yliopiston sisällä tutkimuksen ja opetuksen välisellä vuorovaikutuksella on luontainen sija, sillä monet tutkijat opettavat ja opettajat tutkivat. Niinpä opetuksen sisällöt nousevat tutkimuksesta ja toisaalta opetustyö voi synnyttää uusia tutkimusaiheita. Kaikki tutkijat eivät kuitenkaan opeta, eivätkä kaikki opettajat tee tutkimusta. Niinpä tutkimuksen ja opetuksen väliseen vuorovaikutukseen liittyy myös toisenlaisia näkökulmia. Tutkija saattaa tahollaan pohtia, miten löytäisi osallistujia mielenkiintoiseen tutkimukseen tai miten oman tutkimuksen tulokset tavoittaisivat ne, joille tuloksista olisi hyötyä toiminnassa ja sen kehittämisessä. Opettaja puolestaan saattaa kaivata tutkimustietoa ja sen pohjalta kumpuavia uusia näkökulmia ja ideoita pedagogiseen kehittämiseen. Arjessa tarpeet eivät välttämättä kohtaa.

Tutkimuksen perusteella tiedetään, että vuorovaikutus on paitsi viestien lähettämistä, vastaanottamista ja tulkintaa, myös merkitysten luomista, jakamista, vaihtamista ja neuvottelemista, mikä taas edellyttää vuorovaikutussuhteen rakentamista ja rakentumista. Kun kyse on omasta tutkimuksesta ja opetuksesta, on vuorovaikutussuhteen rakentaminen itsensä kanssa yleensä varsin helppoa. Vaikeampaa siitä tulee silloin, kun mukana on useita henkilöitä ja instituutioita.

\section{Lopuksi}

Kompleksisten haasteiden äärellä yhdessä tekeminen kannattaa, mutta vaarana on, että tarkastelemme ilmiötä kukin omasta näkökulmastamme ymmärtämättä kuitenkaan ongelman tai ilmiön kokonaisuutta ja kompleksisuutta. Niinpä tarvitaan monia näkökulmia ja tulkinnan tasoja sekä vuorovaikutusta niiden välillä.

Vuorovaikutuksen aikaa, paikkaa ja muotoa voidaan tarkastella myös tutkimuksen prosessin näkökulmasta. Miten vuorovaikutus näkyy tutkimusprosessin eri vaiheissa - tutkimusongelman määrittelemisessä, tutkimuksen suunnittelussa, aineiston keruussa, aineiston analyysissa ja tutkimustulosten raportoinnissa?

Ehkä on tarpeen pohtia myös lähtöasetelmaa vuorovaikutukseen (vrt. Cameron ym. 2003). Nähdäänkö esimerkiksi opettajat ja opiskelijat tutkimukseen osallistujina, tulosten soveltajina vai kanssatutkijoina? Kutsutaanko heitä osallistumaan tutkimukseen vai rakentamaan uutta tietoa yhdessä?

Entä millainen on vuorovaikutuksen aikajänne? Rakennetaanko vuorovaikutussuhteita ensisijaisesti hankkeiden keston vai pidempiaikaisen yhteistyön näkökulmasta? Entä kuinka usein tutkijat palaavat tutkimuspaikalle myöhemmin katsomaan, mitä siellä on tapahtunut? Ollaanko kiinnostuneita siitä, kuinka kestäviä ratkaisuja on pystytty kehittämään?

Soveltavan kielitieteen menetelmällisten käänteiden tarkastelu johdattaa perustavaa laatua olevien kysymysten äärelle ja herättää pohtimaan tutkimuksen ta- 
voitteita eli sitä, mitä tutkitaan, miksi ja ketä varten. Niin ikään on tarpeen tarkastella myös sitä, miten tutkimusprosessi etenee eli millaisin menetelmin ja aineistoin tutkimusta tehdään, kenen kanssa ja kuka tutkii. Nämä kaksi edellä mainittua näkökulmaa johdattavat ajattelemaan myös tutkimuksen tuloksia ja vaikuttavuutta uudella tavalla: miten tutkimusprosessi pyrkii ratkaisemaan kieleen liittyviä arjen ongelmia?

\section{Kirjallisuus}

Hellermann, J. 2015 (Ed.). Special issue: definitions for applied linguistics. Applied Linguistics, 36 (4).

Irwin, T. \& Kossoff, G. 2020. Wicked problems. Transition Design Seminar 2020. Saatavilla verkossa:

https://transitiondesignseminarcmu.net/classes-2/systems/\#1482254259729-27721fa6-4857

Jakonen, T., Jalkanen, J., Paakkinen, T. \& Suni, M. 2015. Kielen oppimisen virtauksia ja pedagogiikan pyörteitä: näkökulmia tutkimukseen ja laajeneviin oppimisympäristöihin. Teoksessa Jakonen, T., Jalkanen, J., Paakkinen, T. \& Suni, M. (toim.). Kielenoppimisen virtaukset - Flows of language learning. Suomen soveltavan kielitieteen yhdistyksen julkaisuja 73. Jyväskylä, Finland: Association Finlandaise de Linguistique Appliquée.

Pöyhönen, S. \& H. Paulasto 2020. Kieli ja taide. Lähtökohtia, menetelmiä ja tulevaisuuden suuntia. Teoksessa H. Paulasto, \& S. Pöyhönen (toim.) 2020. Kieli ja taide - soveltavan kielentutkimuksen ja taiteen risteämiä. Language and the arts - creative inquiry in applied linguistics. AFinLA-e. Soveltavan kielitieteen tutkimuksia n:o 74. i-xx. 